\title{
Current Account Balances and Output Volatility
}

\author{
Ceyhun Elgin* \\ Bogazici University \\ Tolga Umut Kuzubas ${ }^{\dagger}$ \\ Bogazici University
}

\begin{abstract}
:
Using annual data from 185 countries over the period from 1950 to 2009, we examine the empirical relationship between current account balance and output volatility in a panel data framework. In a static panel data framework we find that a larger current account deficit is associated with a higher volatility, particularly so in emerging market economies. We also find that this association strongly interacts with GDP per-capita. Moreover, taking the possible endogeneity and feedback effects into account, we also use a Panel-VAR framework and in this case find that output volatility gives a significant positive response to a shock in the current account balance and a negative response to the shocks on GDP per-capita capita.
\end{abstract}

Keywords: current account balances, business cycle volatility, panel data

JEL Classification Numbers: C33, E32, F43.

*Address: Bogazici University, Department of Economics, Natuk Birkan Building, 34342 Bebek, Istanbul, (Turkey). e-mail: ceyhun.elgin@boun.edu.tr.

$\dagger$ Corresponding author. Address: Bogazici University, Department of Economics, Natuk Birkan Building, 34342 Bebek, Istanbul, (Turkey). E-mail: umut.kuzubas@boun.edu.tr, Phone: +90212-359-7641, Fax: +90-212-287-2453. 


\section{Introduction}

Current account (CA) imbalances are among the major concerns of policy makers. Considering the saving-investment nexus, CA balances are very much related to the key factors of economic growth such as private savings and fiscal balance. In that regard, they raise issues of sustainability which is perceived as a major risk in developing countries.

Understanding the factors that influence fluctuations in the CA as well as how CA imbalances affect an economy could have important macroeconomic and policy implications which will shed light on the assessment of its sustainability, and changes through policy measures (See Faruqee and Isard, 1998 or Lane and Pels, 2012 among many others).

Our focus in this paper is to investigate the linkage between CA imbalances and macroeconomic stability. Particularly, we are motivated from the fact that CA imbalances are generally seen among major sources of macroeconomic instability, not only for emerging markets but also for various developed economies as well. Such an investigation is crucial due to several reasons: First, reflecting the savings investment nexus, the current account balance is related to the status of the fiscal balance and private savings, which are among key factors for economic growth. Second, because the CA balance determines the evolution over time of a country's stock of net claims on (or liabilities to) the rest of the world, i.e. it reflects the inter-temporal decisions of domestic and foreign residents. Third, permanent CA deficits and deteriorating fiscal position of an economy may lead to sudden stops or reversals of capital flows, frequently accompanied by severe recessions.

In this context, Brzozowski and Prusty (2011) show that the effect of output volatility on saving behavior and thereby on the CA balance is conditional on the level of income. Accordingly, for low income countries the impact of GDP volatility on CA balances is negative, whereas higher GDP volatility has more adverse impact on investment as compared to its positive impact on domestic savings in a low income economy. In another paper, Chinn and Prasad (2003) report a positive correlation between the relative income and CA imbalances. Their account for this observation is that less-developed countries are expected to grow faster 
than the developed ones therefore are in need to borrow more. Moreover, Sarisoy-Guerin (2006) examined the relationship between net capital inflows and CA in a set of industrial an developing countries and concluded that inflows do no cause CA imbalances nor does the inflow volatility affect current account volatility in the industrial countries. The reason behind this observation is that most industrial countries can borrow and lend relatively easily, whereas most developing countries are mostly liquidity constrained. The restriction for developing countries to borrow from international markets, and mostly determined by foreign investors willingness to lend lead to a liquidity crisis in economic downturns.

Aiming to contribute to this literature, in this paper we examine the two-way relationship between CA balances and output volatility using an unbalanced cross-country panel data set consisting of 185 countries and over a time span of 60 years between 1960 and 2009 . The availability of the panel data allows us to examine both the cross-country and timeseries variation in the output volatility and CA balances. We use both static and dynamic panel data techniques as well as the Panel-VAR approach a la Holtz-Eakin et al. (1988) and check whether there is any shor-run or long-run relationships between output volatility and CA balances. In the static and dynamic panel data analysis we find that the relationship between current account balances and output volatility strongly interacts with GDP percapita. Specifically, our analysis suggest that a larger current account deficit is associated with a higher volatility, particularly so in emerging market economies.

In a Panel-VAR framework with three endogenous variables, namely output volatility, CA balance and GDP per capita, we find that output volatility gives a significant positive response to $\mathrm{CA}$ deficit and negative response to per capita income.

The rest of the paper is organized as follows: In the next section we shortly discuss the econometric methodology we use and describe our dataset. In the third section we present the estimation results. Finally, in the last section we provide concluding remarks and a short discussion. 


\section{Methodology and Data}

\subsection{Econometric Methodology}

\subsubsection{Static Panel Data Analysis}

For the benchmark analysis, we first estimate the following relationship in the static panel data setting:

$$
\operatorname{vol}_{i, t}=\beta_{0}+\beta_{1} c a_{i, t}+\sum_{k=2}^{n} \beta_{k} X_{k_{i, t}}+\theta_{i}+\gamma_{t}+\epsilon_{i, t}
$$

Here, for country $i$ in year $t, \operatorname{vol}_{i, t}$ refers to volatility of output, ca $a_{i, t}$ denotes the current account balance as $\%$ of GDP and $X_{k_{i, t}}$ are the control variables. Moreover, $\theta_{i}$ and $\gamma_{t}$ are the country and year fixed effects and $\epsilon_{i, t}$ denotes the error term.

In the first set of regressions, we will use the fixed-effect estimator in the static panel data setting. However, one might very much suspect the potential endogeneity of the current account balances as well as other control variables used in the above regression equation. Moreover, to capture persistence and also potentially mean-reverting dynamics in volatility we also report results of the dynamic panel data estimation using the GMM estimator developed by Arellano and Bond (1991) where one-period lagged values of the regressors are used as instruments. ${ }^{1}$ In this case we estimate the following equation in the dynamic panel data setting:

$$
\operatorname{vol}_{i, t}=\beta_{0}+\beta_{1} \operatorname{vol}_{i, t-1}+\beta_{2} c a_{i, t}+\beta_{3} i s_{i, t}^{2}+\sum_{k=4}^{n} \beta_{k} X_{k_{i, t}}+\theta_{i}+\gamma_{t}+\epsilon_{i, t}
$$

In the dynamic panel data estimations, p-values corresponding to two tests are also provided in all of the tables. One of these tests is the Hansen J-test for over-identifying

\footnotetext{
${ }^{1}$ Further estimations has been conducted to address potential existence of a two-directional causality between current account balances and volatility of output. We also run regressions using the IV estimator of Anderson and Hsiao (1982). Results are qualitatively similar to the reported regression outputs and these are also available upon request from the corresponding author.
} 
restrictions and the other one is the AR (2) test for autocorrelation. The tests provide support for the exogeneity of the instruments and absence of autocorrelation in the specified order, respectively.

\subsubsection{Panel-VAR}

In the second set of regressions, we use a panel-data vector autoregression (VAR) methodology which we think fits the purpose of this paper well. As well known, this method extends the traditional VAR approach to a panel data setting and allows us to control for country level heterogeneity. In this case, in the estimated model, we treat both output volatility and current account balance as endogenous (along GDP per-capita) and pose the following specification:

$$
y_{i t}=\sum_{j=1}^{p} \beta_{j} y_{i, t-j}+\sum_{j=1}^{p} \delta_{j} x_{i, t-j}+f_{i}+s_{c, t}+v_{i t}
$$

In order to deal with the problem associated with introducing lagged dependent variables in a fixed or random effect model, we rely on the methodology proposed by Holtz-Eakin (1988) and to control for country level heterogeneity we have introduced fixed effects, $f_{i}$ in the model. The mean-differencing which is commonly used in panel estimation will lead to biased estimates, therefore we have used forward mean-differencing, known as "Helmert procedure" which allows us to use lagged dependent variables as instruments and ensure identification. We also include time dummies for each country in order to capture country level shocks to macroeconomic conditions. These dummies are eliminated by subtracting the means of each variable calculated for each country-year.

Applying the VAR methodology to panel data presents a problem associated with lagged dependent variables in both fixed and random effects settings. In order to address this problem we use the methodology proposed by Holtz-Eakin (1988). In the traditional VAR, one needs to impose the restriction that the data generating process is the same for each cross-section of observation which is hardly met in practice. Therefore, in order to control 
for individual level heterogeneity we introduce fixed effects, $f_{i}$ in the model. In the VAR setting, because of the dynamic nature of the estimation, lagged dependent variables are correlated with the disturbance term. For the fixed effect estimator transformation of variables eliminates $f_{i}$ however, the regressor $y_{i t-1}-\bar{y}_{i .-1}$, with $\bar{y}_{i .-1}=\sum_{t=p+1}^{T} y_{i t-1} /(T-p)$, will still be correlated with the error term $v_{i t}-\bar{v}_{i .}$, where $\bar{v}_{i .}=\sum_{t=p+1}^{T} v_{i t} /(T-p)$, because $y_{i t-1}$ is correlated with $\bar{v}_{i}$. by construction. Therefore, the mean-differencing procedure commonly used to eliminate fixed effects would create biased coefficients especially with a limited number of time-series observations. In order to eliminate this problem, we use forward mean-differencing, known as the "Helmert procedure". This transformation satisfies the orthogonality assumption between transformed variables and lagged regressors. Therefore, we can use lagged dependent variables as instruments and estimate the coefficients by system GMM. (see Love and Zicchino (2006) and Arellano and Bover (1995) for more details.). We also include time dummies for each country in order to capture country level shocks to macroeconomic conditions. These dummies are eliminated by subtracting the means of each variable calculated for each country-year.

A model with individual effects that relaxes the time stationarity assumption is the one we use in our estimation, where we modify the empirical model as follows:

$$
y_{i t}=\alpha_{0 t}+\sum_{j=1}^{m} \alpha_{j t} y_{i, t-j}+\sum_{j=1}^{m} \gamma_{j} x_{i, t-j}+f_{i}+u_{i t}
$$

where $\mathrm{y}$ and $\mathrm{x}$ will be the endogenous variables we use in our specification and $f_{i}$ is the unobserved individual effect.

Before, estimating this system, we will first use a second generation unit root test developed by Pesaran (2007) which is based on the augmentation of the Augmented DickeyFuller regression with lagged cross-sectional mean and its first difference capturing the crosssectional dependence. We will use the critical values reported in this paper with the null hypothesis of the presence of the unit root. ${ }^{2}$ Moreover, we will also test the presence of

\footnotetext{
${ }^{2}$ We have also employed several other panel unit-root tests and obtained similar results. These are also
} 
cointegration for the variables having a unit-root. If such a relationship does not exist, then we will use the first-differences series in a Panel VAR analysis.

Finally, once the estimation is done, we analyse impulse-response functions and also present variance decompositions. Following Love and Zicchino (2006) we calculate standard errors of the impulse functions generating confidence intervals using Monte-Carlo simulations. $^{3}$

\subsection{Data}

Based on observation s for 185 countries over the period from 1950 to 2010, we use three variables in our empirical analysis. These are CA balance as \% GDP, PPP converted GDP per-capita (in 2005 prices) and volatility as measured by the absolute value of the difference between the growth rate of country $i$ in year $t$ and country i's average growth rate over the 60-year period. ${ }^{4}$ This is one of the most widely used measures of output volatility in the literature. We obtained all the series from Penn World Tables 7.1. (PWT)

Moreover, in our static an dynamic panel data analysis, we also use several control variables. These are trade openness (defined as the ratio of the sum of exports and imports to GDP), government spending (as \% of GDP), inflation (calculated based on the GDP deflator) and three institutional quality indices, namely the government stability, law and order and democratic accountability indices. We obtained these indices from the International Country Risk Guide of the PRS Group and the rest of the variables from PWT.

Table 1 provides descriptive statistics of all three variables.

\section{Table 1 about here}

Before we go into the details of the empirical analysis, we illustrate a key fact in figures 1 and 2. Here, we divide our dataset into two: Countries with GDP per-capita below the available upon request from the corresponding author.

${ }^{3}$ Reported results are based on 1000 Monte-Carlo simulations. Our results are qualitatively similar when one performs different numbers of simulations.

${ }^{4}$ We examined several other volatility measures used in the literature as well. Results are qualitatively similar. 
mean of our sample (denoted by low income countries) and countries above that. Figure 1 then plots volatility against current account balances for low income countries. On the other hand, Figure 2 plots the same variables for high income countries.

Figures 1 and 2 about here

When we compare these two graphs, we observe a striking difference. For low income economies, a larger current account deficit is associated with higher volatility of output; whereas this is not true for higher income economies. This indicates, at least in terms of plain correlations, GDP per-capita strongly interacts with the relationship between current account balances and volatility. However, we need to further verify this with a more detailed econometric analysis. This we will do in the next section.

\section{Estimation Results}

\subsection{Static/Dynamic Panel Data Estimations}

Tables 2 and 3 about here

Static and dynamic panel data regression results are reported in Table 2 and 3, respectively. Booth tables report three sets of regressions. The first three reports the regressions with the whole dataset. The regressions, (4), (5), and (6) report the regressions for low income economies, whereas the last three do the same analysis with high income countries. In both tables, for the first six regressions, we observe that a lower current account balance (or a higher deficit) is associated with higher volatility of output. Moreover, this association is much stronger when GDP per-capita is lower. This is true both for the whole dataset and for the subset of low income countries. However, in line with Figure 2, the robustness of this relationship is broken when we limit out analysis to the subset of high income economies. Besides the current account balance and GDP per-capita we also observe that government stability is a robust determinant of volatility as its coefficient is significant in both sets of 
regressions. Accordingly, countries with more (less) stable government experience a lower (higher) rate of output volatility.

\subsection{Panel-VAR Results}

Table 4 about here

As discussed in the previous section, we first conduct a unit-root test on all the variables used in the analysis. To this end, Table 4 reports the results of the CADF panel unit root test a la Pesaran (2007). ${ }^{5}$ According to the results reported in Table 4, three variables, namely, the null hypotheses that the levels of CA balance, GDP per-capita and output volatility have unit roots, cannot be rejected. As we reject these hypotheses for their first differences, we conclude that they are integrated of order one. On the other hand, the rest of the variables are stationary even in their levels.

Table 5 about here

Next, in Table 5 we report the results of the cointegration test developed by Westerlund (2007). Here, we test whether a cointegrating relationship exists between CA balance, GDP per-capita and output volatility. Basicaly, our aim here is to test for the absence of cointegration which we conduct by determining whether error correction exists for the panel as a whole or for individual panel members. This test also also takes through bootstrapping cross-section interdependence into account. Here the null hypothesis is that the cointegration does not exist. The $\mathrm{G}_{\tau}$ and $\mathrm{G}_{\alpha}$ statistics test whether cointegration exists for at least one country whereas the $\mathrm{P}_{\tau}$ and $\mathrm{P}_{\alpha}$ statistics pool information over all the individual country series and test whether a cointegrating relationship exists for the panel as a whole. Moreover, cross-section interdependence is taken into account by computing the robust p-value is through bootstrapping with 1000 replications. According to the results in Table 5, we cannot reject the null hypothesis of no cointegration in any of the four tests.

\footnotetext{
${ }^{5}$ Again, we also conducted several other unit root tests and ended up with similar results.
} 
As we do not find evidence of cointegration between the three variables having the unit root, we now estimate them in a VAR setting in first differences.

Table 6 about here

Table 6 reports the estimated coefficients of the system once the fixed effects and the country-time dummy variables are removed. Particularly, Table 6 illustrates estimation results of 3 different systems, one using the whole 185-country sample, another one using a subsample only with countries countries below the average GDP per-capita of the sample and finally a sub-sample only with countries having a GDP per-capita above the mean of the sample. What we observe from Table 6 is that both for the whole sample and the sample of low income countries, the volatility gives a robust and significantly negative response to shocks to current account balance (therefore a positive response to current account deficit) and negative response to shocks to GDP per-capita. However, for the sample of high income countries we do not observe a significant response. Again, these results are in line with figures 1 and 2, reported earlier.

Figure 3 presents the impulse-response functions and the $5 \%$ error bands generated by Monte-Carlo simulations. What we observe from Figure 3 is in line with the results presented in Table 6, that is, volatility gives a significant positive shock to the deterioration of the CA balances.

Finally, in Table 7 we present variance decompositions corresponding to the estimations presented in Table 6. In all samples, CA balances explains more of the volatility variation 10 periods ahead in our sample, compared to the GDP per-capita. However, the magnitude of the effect is larger for sample of low income economies.

\section{Conclusion}

We used data from 185 countries over the period from 1950 to 2009 and examined the relationship between CA balance and output volatility using a Panel-VAR framework. To the 
best of our knowledge, this is the first paper which employs this methodology to this relationship. We find that output volatility gives a significant positive response to the deterioration of the CA balances, however a negative response to GDP per-capita. This result indicates how crucial CA imbalances are in affecting business cycles. Moreover, further research is needed to investigate the potential mechanisms behind this observation. 


\section{References}

Arellano, M. and Bover, O. (1995) Another look at the instrumental variable estimation of error-components models, Journal of Econometrics, 68(1), pages 29-51.

Brzozowsk, M. and Prusty, S. (2011) Impact of GDP volatility on current account balances, Working Papers 2011-02, Faculty of Economic Sciences, University of Warsaw.

Chinn, M. D. and Prasad, E. S. (2003) Medium-term determinants of current accounts in industrial and developing countries: an empirical exploration, Journal of International Economics, 59(1), 47-76.

Faruqee, H. and Isard, P. (1998) Exchange Rate Assessment: Extension of the Macroeconomic Balance Approach, IMF Occasional Papers 167, International Monetary Fund.

Holtz-Eakin, D., Newey, W. K. and Rosen, H. S. (1988) Estimating Vector Autoregressions with Panel Data, Econometrica, 56, 1371-95.

Lane, P. and Pels, B., (2012) Current Account Imbalances in Europe, IIIS Discussion Paper, No. 397.

Love, I. and Zicchino, L. (2006) Financial development and dynamic investment behavior: Evidence from panel VAR, The Quarterly Review of Economics and Finance, 46(2), 190-210.

Pesaran, M. H. (2007) A Simple Panel Unit Root Test in the Presence of Cross-Section Dependence. Journal of Applied Econometrics 27 (2), 265-312.

Sarisoy-Guerin, S. (2006) The Relationship Between Capital Flows and Current Account: Volatility and Causality, LUISS working paper 36.

Westerlund, J. (2007). Testing for Error Correction in Panel Data. Oxford Bulletin of Economics and Statistics, 69 (6), 709-748. 


\section{Appendix: Figures and Tables}

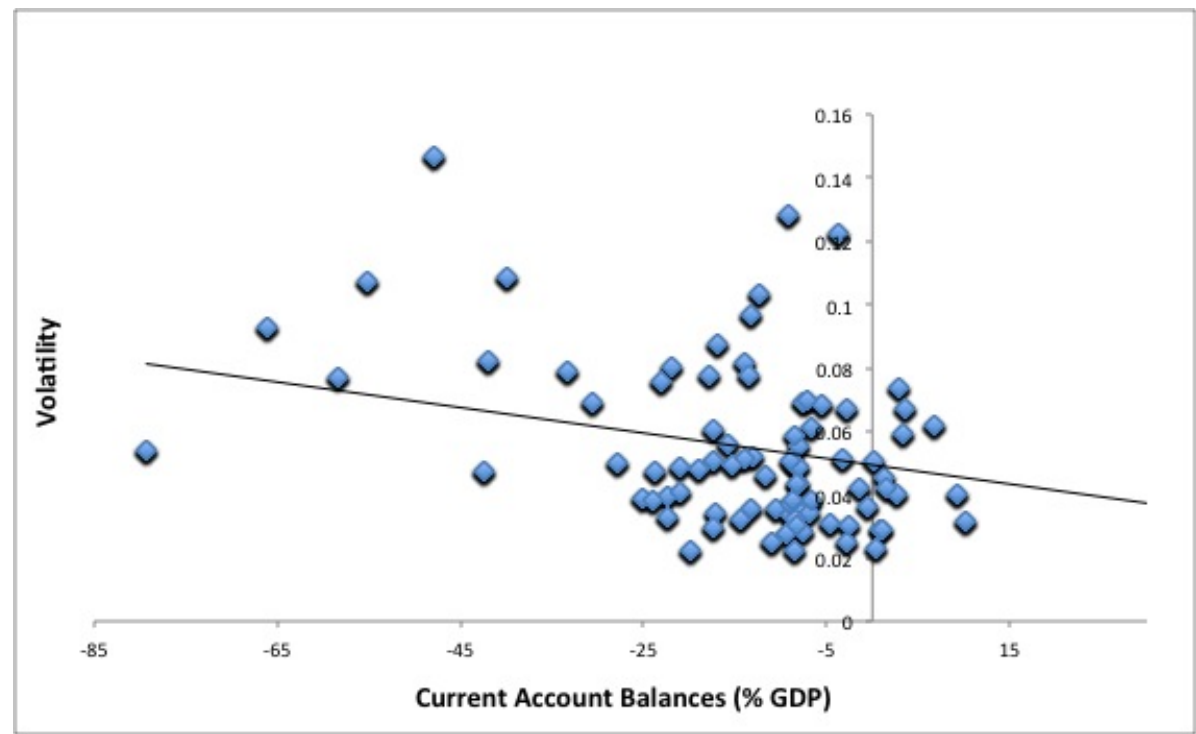

Figure 1: Volatility vs. CA Balances: Low Income Countries

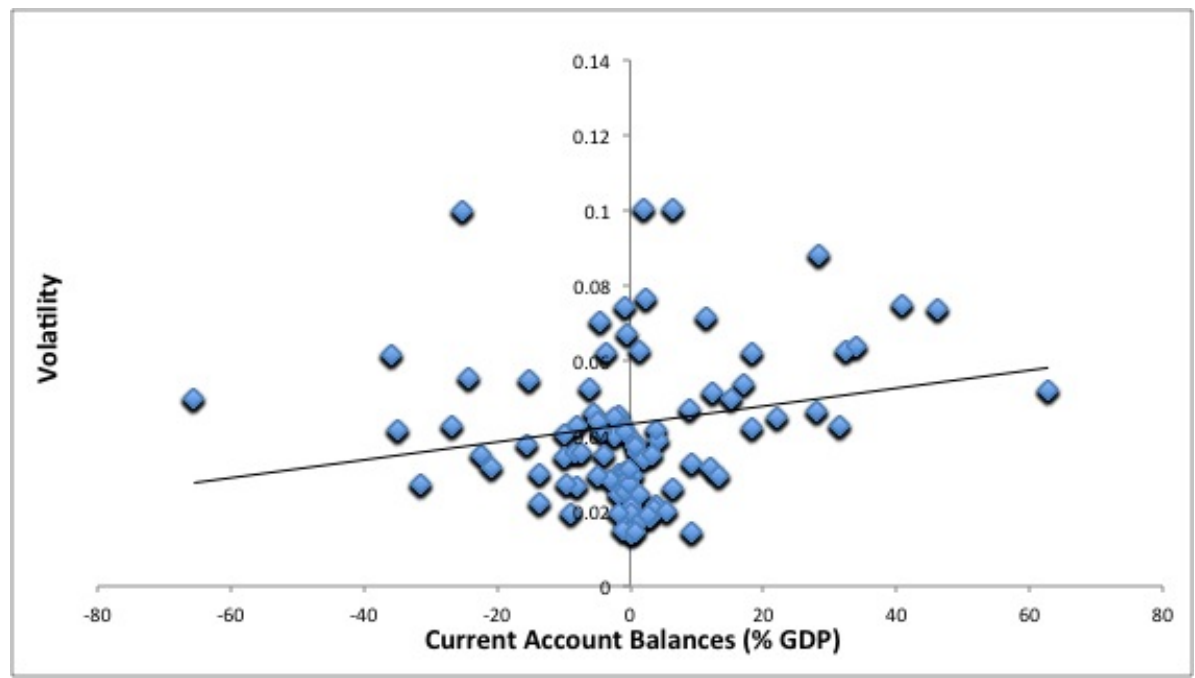

Figure 2: Volatility vs. CA Balances: High Income Countries 


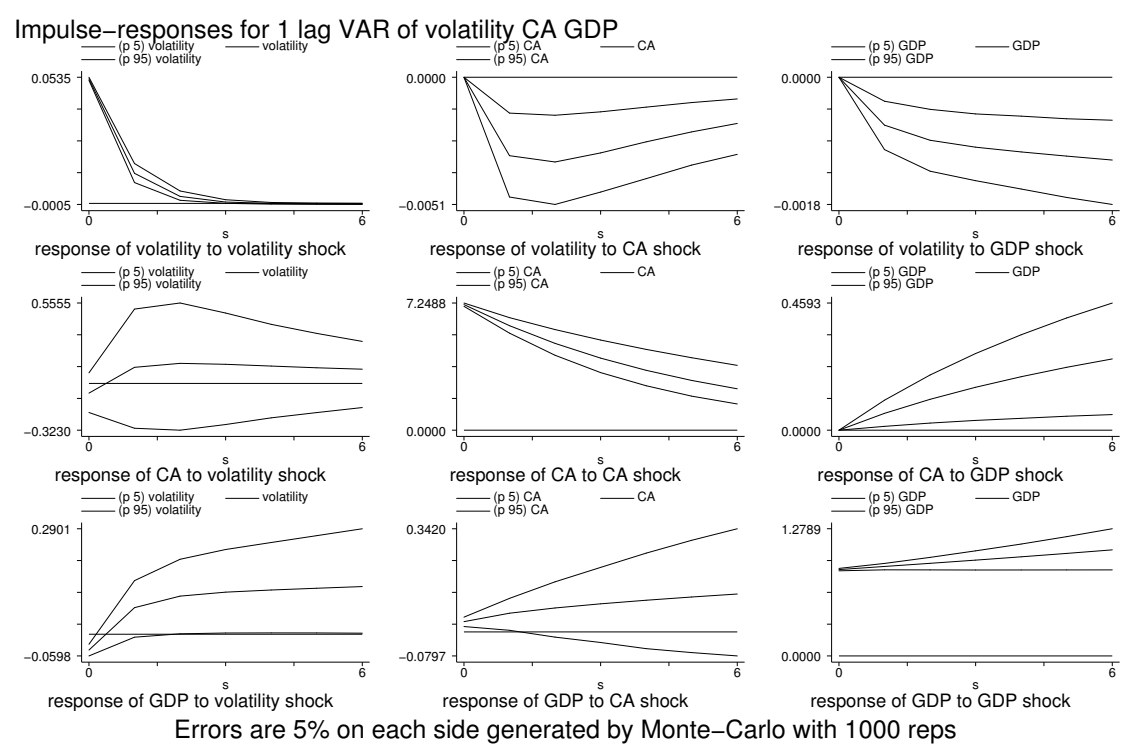

Figure 3: Impulse Response Functions

Table 1: Complete Dataset Summary Statistics

\begin{tabular}{llllll}
\hline \hline & Mean & Std. Dev. & Min. & Max. & Range \\
\hline \hline Current Account Balance (\% GDP) & -5.64 & 21.34 & -193.64 & 88.85 & $1950-2010$ \\
GDP per-capita (in thousand USD) & 8.42 & 11.04 & 0.14 & 159.14 & $1950-2010$ \\
Volatility & 0.04 & 0.06 & 0.00 & 0.38 & $1951-2010$ \\
\hline Openness (\% GDP) & 68.43 & 49.23 & 2.32 & 443.18 & $1950-2010$ \\
Government exp. ((\%)GDP) & 10.83 & 7.27 & 0.28 & 58.59 & $1950-2010$ \\
Democratic Accountability & 3.82 & 1.62 & 0.00 & 6.00 & $1984-2010$ \\
Government Stability & 7.70 & 2.17 & 1.00 & 12.00 & $1984-2010$ \\
Law and Order & 3.70 & 1.47 & 0.00 & 0.00 & $1984-2010$ \\
Inflation (\%) & 7.78 & 7.11 & -17.18 & 165.62 & $1960-2010$ \\
\hline \hline
\end{tabular}


Table 2: Volatility and Current Account Balances: FE Estimations

\begin{tabular}{llll|lll|lll} 
Volatility & $(1)$ & $(2)$ & $(3)$ & $(4)$ & $(5)$ & $(6)$ & $(7)$ & $(8)$ & $(9)$ \\
\hline \hline CA & $-0.01^{* *}$ & $-0.02^{* *}$ & $-0.03^{*}$ & $-0.07^{*}$ & $-0.07^{*}$ & $-0.08^{*}$ & $-0.02^{* * *}$ & $-0.02^{* * *}$ & -0.03 \\
& $(2.07)$ & $(2.11)$ & $(3.07)$ & $(4.17)$ & $(4.08)$ & $(3.98)$ & $(1.79)$ & $(1.75)$ & $(1.21)$ \\
GDP & $-0.004^{*}$ & $-0.01^{*}$ & $-0.01^{*}$ & $-0.02^{* *}$ & $-0.02^{* *}$ & $-0.01^{* * *}$ & $-0.001^{* *}$ & $-0.001^{* *}$ & $-0.001^{* *}$ \\
& $(2.76)$ & $(2.75)$ & $(2.85)$ & $(2.15)$ & $(2.01)$ & $(1.78)$ & $(2.01)$ & $(2.04)$ & $(1.98)$ \\
CA.GDP & $0.001^{*}$ & $0.001^{*}$ & $0.001^{*}$ & 0.002 & 0.001 & -0.001 & -0.001 & -0.002 & 0.002 \\
& $(3.10)$ & $(3.02)$ & $(3.04)$ & $(1.34)$ & $(0.75)$ & $(0.82)$ & $(1.04)$ & $(0.84)$ & $(0.90)$ \\
Openness & & 0.04 & 0.07 & & $0.03^{* *}$ & $0.03^{* *}$ & & $-0.001^{* *}$ & $-0.002^{*}$ \\
& & $(0.77)$ & $(1.01)$ & & $(2.17)$ & $(2.09)$ & & $(2.00)$ & $(2.90)$ \\
Govt. Sp. & & -0.01 & -0.04 & & 0.01 & -0.07 & & 0.05 & 0.04 \\
& & $(0.49)$ & $(0.27)$ & & $(0.05)$ & $(0.08)$ & & $(0.15)$ & $(0.14)$ \\
Law & & -0.14 & & & -0.17 & & 0.19 \\
Democracy & & & $(0.84)$ & & & $(0.45)$ & & $(0.67)$ \\
Gov. St.. & & & 0.12 & & & 0.93 & & $-0.29^{* *}$ \\
Inflation & & & $(1.45)$ & & & $(0.64)$ & & $(1.98)$ \\
& & & $-0.09^{* *}$ & & & $-0.11^{* * *}$ & & & $-0.17^{*}$ \\
Constant & $0.04^{*}$ & $0.05^{*}$ & $0.10^{*}$ & $0.21^{*}$ & $0.20^{*}$ & $0.27^{*}$ & $0.11^{* *}$ & $0.10^{* *}$ & $0.12^{* *}$ \\
& $(4.99)$ & $(7.10)$ & $(6.56)$ & $(5.12)$ & $(4.88)$ & $(3.90)$ & $(2.14)$ & $(2.17)$ & $(2.08)$ \\
\hline R-squared & 0.11 & 0.11 & 0.16 & 0.17 & 0.18 & 0.19 & 0.12 & 0.12 & 0.13 \\
Observations & 8283 & 8283 & 3201 & 4151 & 4151 & 1601 & 4132 & 4132 & 1600 \\
F-Test & 17.45 & 14.15 & 8.03 & 11.20 & 10.03 & 8.77 & 13.67 & 11.26 & 10.01 \\
Time F-Test & 0.01 & 0.01 & 0.00 & 0.00 & 0.00 & 0.00 & 0.00 & 0.01 & 0.00 \\
\hline
\end{tabular}

All panel regressions include a country fixed effect and year dummies. Time F-test gives the p-value for the joint significance of year dummies. Absolute values of robust t-statistics are reported in parentheses. *, **, *** denote 1,5 and $10 \%$ confidence levels, respectively. 
Table 3: Volatility and Current Account Balances: GMM Estimations

\begin{tabular}{|c|c|c|c|c|c|c|c|c|c|}
\hline & $(1)$ & $(2)$ & $(3)$ & $(4)$ & $(5)$ & $(6)$ & $(7)$ & $(8)$ & $(9)$ \\
\hline $\mathrm{CA}$ & $\begin{array}{l}-0.04^{*} \\
(2.97)\end{array}$ & $\begin{array}{l}-0.04^{*} \\
(3.11)\end{array}$ & $\begin{array}{l}-0.04^{*} \\
(3.10)\end{array}$ & $\begin{array}{l}-0.07^{*} \\
(3.65)\end{array}$ & $\begin{array}{l}-0.08^{*} \\
(3.68)\end{array}$ & $\begin{array}{l}-0.09 * \\
(3.88)\end{array}$ & $\begin{array}{l}-0.02 \\
(0.80)\end{array}$ & $\begin{array}{l}-0.01 \\
(0.56)\end{array}$ & $\begin{array}{l}-0.01 \\
(0.51)\end{array}$ \\
\hline GDP & $\begin{array}{l}-0.01^{* *} \\
(2.23)\end{array}$ & $\begin{array}{l}-0.01^{* *} \\
(2.25)\end{array}$ & $\begin{array}{l}-0.01^{* *} \\
(2.27)\end{array}$ & $\begin{array}{l}-0.01^{* *} \\
(2.40)\end{array}$ & $\begin{array}{l}-0.01^{* *} \\
(2.22)\end{array}$ & $\begin{array}{l}-0.01^{* *} \\
(2.18)\end{array}$ & $\begin{array}{l}-0.01^{* * *} \\
(1.71)\end{array}$ & $\begin{array}{l}-0.02^{* * *} \\
(1.74)\end{array}$ & $\begin{array}{l}-0.02^{* * *} \\
(1.78)\end{array}$ \\
\hline $\mathrm{CA} \cdot \mathrm{GDP}$ & $\begin{array}{l}0.001^{* *} \\
(2.04)\end{array}$ & $\begin{array}{l}0.001^{* *} \\
(2.02)\end{array}$ & $\begin{array}{l}0.001^{* *} \\
(2.11)\end{array}$ & $\begin{array}{l}0.001^{* * *} \\
(1.74)\end{array}$ & $\begin{array}{l}0.001^{* * *} \\
(1.75)\end{array}$ & $\begin{array}{l}0.001^{* * *} \\
(1.72)\end{array}$ & $\begin{array}{l}0.002 \\
(0.94)\end{array}$ & $\begin{array}{l}0.002 \\
(0.90)\end{array}$ & $\begin{array}{l}0.002 \\
(0.89)\end{array}$ \\
\hline Openness & & $\begin{array}{l}0.03^{* * *} \\
(1.77)\end{array}$ & $\begin{array}{l}0.02^{* * *} \\
(1.71)\end{array}$ & & $\begin{array}{l}0.03^{*} \\
(3.01)\end{array}$ & $\begin{array}{l}0.03^{*} \\
(2.99)\end{array}$ & & $\begin{array}{l}0.01 \\
(1.00)\end{array}$ & $\begin{array}{l}0.01 \\
(0.82)\end{array}$ \\
\hline Govt. Sp. & & $\begin{array}{l}0.05 \\
(0.99)\end{array}$ & $\begin{array}{l}0.04 \\
(0.97)\end{array}$ & & $\begin{array}{l}0.06 \\
(0.65)\end{array}$ & $\begin{array}{l}0.06 \\
(0.68)\end{array}$ & & $\begin{array}{l}-0.07 \\
(0.45)\end{array}$ & $\begin{array}{l}-0.06 \\
(0.42)\end{array}$ \\
\hline Law & & & $\begin{array}{l}-0.19 \\
(0.54)\end{array}$ & & & $\begin{array}{l}-0.18 \\
(0.42)\end{array}$ & & & $\begin{array}{l}0.20 \\
(0.47)\end{array}$ \\
\hline Democracy & & & $\begin{array}{l}0.09^{* * *} \\
(1.81)\end{array}$ & & & $\begin{array}{l}0.03 \\
(0.61)\end{array}$ & & & $\begin{array}{l}-0.12^{* * *} \\
(1.73)\end{array}$ \\
\hline Gov. St.. & & & $\begin{array}{l}-0.05^{* *} \\
(2.00)\end{array}$ & & & $\begin{array}{l}-0.10^{* *} \\
(2.08)\end{array}$ & & & $\begin{array}{l}-0.11^{* *} \\
(2.05)\end{array}$ \\
\hline Inflation & & & $\begin{array}{l}0.65 \\
(0.85)\end{array}$ & & & $\begin{array}{l}0.20 \\
(0.90)\end{array}$ & & & $\begin{array}{l}-0.02 \\
(0.64)\end{array}$ \\
\hline L.Volatility & $\begin{array}{l}0.17^{*} \\
(7.79)\end{array}$ & $\begin{array}{l}0.17^{*} \\
(7.80)\end{array}$ & $\begin{array}{l}0.16^{*} \\
(7.64)\end{array}$ & $\begin{array}{l}0.19^{*} \\
(5.90)\end{array}$ & $\begin{array}{l}0.19^{*} \\
(5.89)\end{array}$ & $\begin{array}{l}0.19^{*} \\
(5.92)\end{array}$ & $\begin{array}{l}0.22^{* *} \\
(6.20)\end{array}$ & $\begin{array}{l}0.20^{*} \\
(6.21)\end{array}$ & $\begin{array}{l}0.22^{*} \\
(6.18)\end{array}$ \\
\hline Constant & $\begin{array}{l}0.04^{*} \\
(8.99)\end{array}$ & $\begin{array}{l}0.04^{*} \\
(8.21)\end{array}$ & $\begin{array}{l}0.05^{*} \\
(7.65)\end{array}$ & $\begin{array}{l}0.09^{*} \\
(9.93)\end{array}$ & $\begin{array}{l}0.05^{*} \\
(9.88)\end{array}$ & $\begin{array}{l}0.03^{*} \\
(9.90)\end{array}$ & $\begin{array}{l}0.06^{*} \\
(7.40) \\
\end{array}$ & $\begin{array}{l}0.07^{*} \\
(7.70)\end{array}$ & $\begin{array}{l}0.06^{*} \\
(8.01) \\
\end{array}$ \\
\hline Observations & 7913 & 7913 & 2831 & 3903 & 3903 & 1353 & 3886 & 3886 & 1354 \\
\hline J-Test & 0.21 & 0.23 & 0.20 & 0.22 & 0.29 & 0.29 & 0.27 & 0.27 & 0.28 \\
\hline AR (2) Test & 0.34 & 0.30 & 0.29 & 0.25 & 0.20 & 0.22 & 0.22 & 0.21 & 0.26 \\
\hline
\end{tabular}

All panel regressions include a country fixed effect and year dummies. Robust z-statistics are reported in parentheses. ${ }^{*},{ }^{* *},{ }^{* *}$ denote 1,5 and $10 \%$ confidence levels, respectively. In all regressions a constant is also included but not reported. 
Table 4: CADF Panel Unit Root Tests

\begin{tabular}{lll|ll}
\hline \multicolumn{3}{l|}{ Level } & First. Diff. & \\
\hline \hline Variable & Test Stat. & P-value & Test. Stat & P-Value \\
\hline \hline CA Balance (\% GDP) & 0.48 & 0.69 & -.3 .13 & 0.00 \\
GDP per-capita (thousand USD) & 1.94 & 0.97 & -3.75 & 0.00 \\
Volatility & 0.14 & 0.56 & -4.20 & 0.00 \\
Openness (\% GDP) & -4.10 & 0.00 & & \\
Government exp. ((\%)GDP) & -1.87 & 0.03 & & \\
Democratic Accountability & -2.11 & 0.00 & & \\
Government Stability & -5.44 & 0.00 & & \\
Law and Order & -4.30 & 0.00 & & \\
Inflation (\%) & -6.99 & 0.00 & & \\
\hline \hline
\end{tabular}

The test statistic is based on the Cross-sectionally Augmented Dickey Fuller (CADF) Test following Pesaran (2007). The test has the null hypothesis of the presence of a unit-root.

Table 5: Panel Cointegration Tests

\begin{tabular}{lll}
\hline \hline Statistic & Value & P-value \\
\hline \hline$G_{\tau}$ & -2.08 & 0.26 \\
$G_{\alpha}$ & -7.66 & 0.99 \\
$P_{\tau}$ & -7.30 & 0.11 \\
$P_{\alpha}$ & -3.64 & 0.14 \\
\hline \hline
\end{tabular}

P-values are robust critical values obtained through bootstrapping with 1000 replications. 
Table 6: Main Results of the Panel-VAR Model

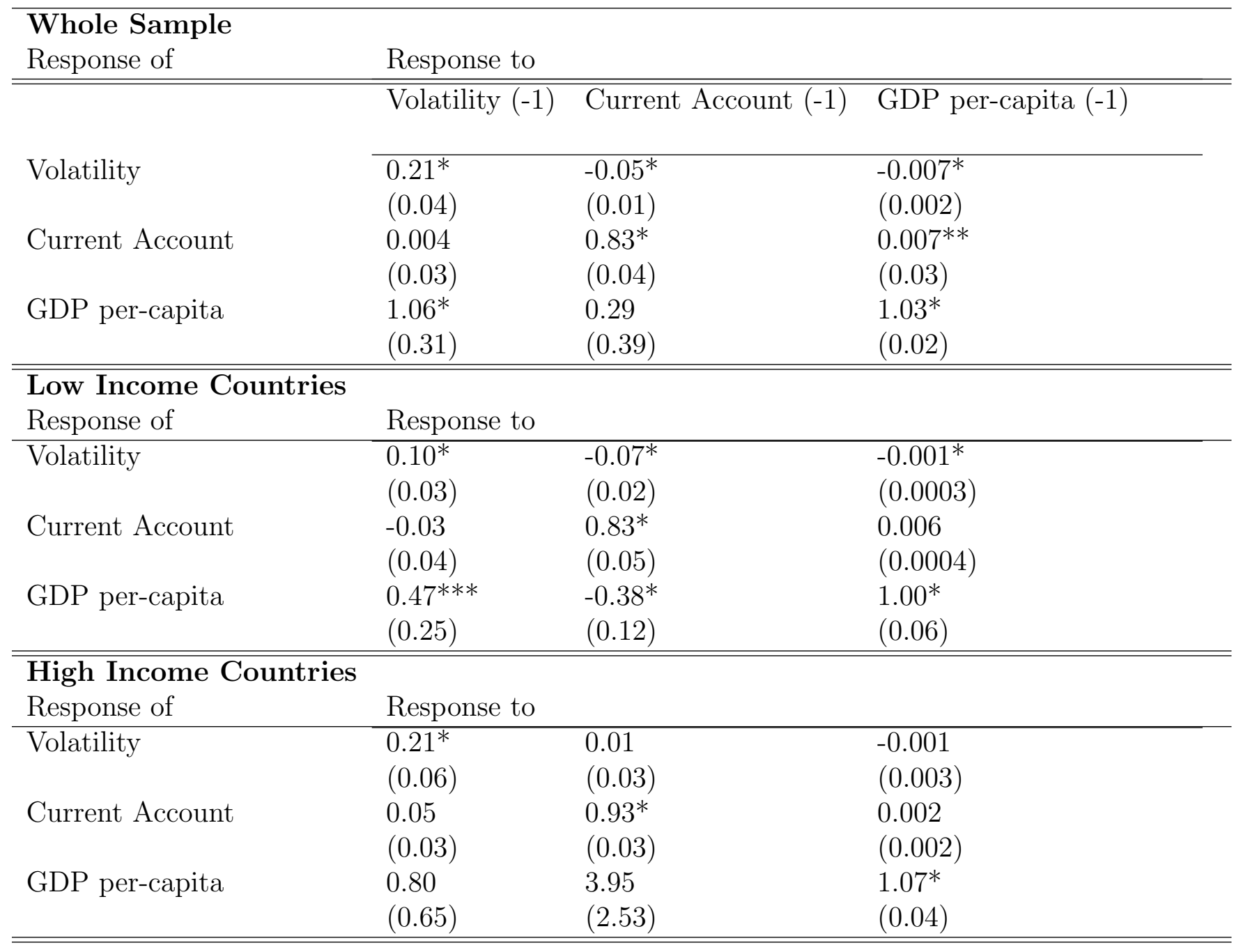


Table 7: Variance Decompositions

\begin{tabular}{llll}
\hline Whole Sample & Volatility & Current Account & GDP per-capita \\
\hline Volatility & 0.84 & 0.15 & 0.01 \\
Current Account & 0.00 & 0.99 & 0.00 \\
GDP per-capita & 0.03 & 0.01 & 0.96 \\
\hline Low Income Countries & & & \\
& Volatility & Current Account & GDP per-capita \\
\hline Volatility & 0.72 & 0.27 & 0.01 \\
Current Account & 0.01 & 0.99 & 0.00 \\
GDP per-capita & 0.08 & 0.01 & 0.91 \\
\hline High Income Countries & & & \\
& Volatility & Current Account & GDP per-capita \\
\hline Volatility & 0.89 & 0.10 & 0.01 \\
Current Account & 0.00 & 0.98 & 0.02 \\
GDP per-capita & 0.02 & 0.02 & 0.96 \\
\hline
\end{tabular}

Percent of variation in the row variable (10 periods ahead) explained by column variable. 